\title{
Bidrag til Aabenraas økonomiske Historie indtil ca. 1730.
}

\section{Af Hans Vald. Gregersen.}

Aabenraas Beliggenhed ved den brede og dybe Aabenraa Fjords inderste Vig, paa alle Sider omgivet af store Skove, har tidligt henvist Aabenraaborgerne til at søge deres Næring paa Havet. I tidligere Tid har Byens Forbindelsesveje med Omverdenen været endog overordentlig ugunstige. Den vigtigste Forbindelse med Oplandet gik i ældre Tid mod Vest til den jyske Halvøs gamle Hovedfærdselsaare: i fredelige Tider Okse- eller Studevejen. i krigsprægede Perioder Hærvejen.

Det middelalderlige Aabenraas vigtigste Erhverv har $v \in I$ været Fiskeriet. Byens Vaaben bærer den Dag i Dag de tre Fisk, og en af Byens ældste Gader er Fiskergade. Ved Siden af Fiskeriet har ogsaa Søfarten tidligt spillet en Rolle. Ikke uden Grund er den nuværende Hovedkirke indviet til de søfarendes Helgen Sankt Nikolaj. Stadsretten fra Aaret 1335, kaldet Skraaen, har da ogsaa betegnende nok en særlig Paragraf om Skipperens Forhold, og meget tyder paa, at Aabenraaborgere har deltaget i Datidens store Sildefiskeri ved Skaanes Øresundskyst.") Som det var Tilfældet med de andre nordiske Byer, stod dog ogsaa Aabenraa hele Middelalderen igennem i Skyggen af Hansebyerne, der helt og holdent beherskede Handelslivet i Østersøomraadet. Efter Aar 1400 begyndte imidlertid danske Konger som Erik af Pommern, Hans og Christian II at interessere sig for Byerhvervene. Af al Magt søgte de saaledes at bekæmpe Hansebyernes, først og fremmest Lübecks, Overmagt i nordisk Handelsliv. Men først under Grevens Fejde blev Hansebyernes Magt endeligt brudt. Christian III og hans Hjælpere arbejdede herefter bevidst paa at ophjælpe de danske Byers Handel. Mange Byer fik deres Privilegier stadfæstet eller fik nye Ret-

1) Skraaen findes trykt i Oversættelse i Vilh. Marstrand: Aabenraa. En egnsplan- og byplanhistorisk unders $\varnothing$ gelse. 
tigheder. Allerede Frederik I havde 14. 6. 1530 bevilget Aabenraa det Marked, som hidtil havde været afholdt ved Ris Kirke paa Maria Magdalene Dag; i 1533 blev Privilegierne bekræftet, hvortil kom Eneret paa al Handel i Amtet, der dengang kun omfattede Sønder Rangstrup og Ris Herreder samt Varnæs Birk. $\left.{ }^{2}\right)$

Aabenraa førte dog foreløbig en ret hensygnende Tilværelse. Den har vel i Midten af 1500-Tallet været en af de mindste Byer i Slesvig. Da der i 1545 skulde stilles et vist Antal Ryttere og Fodfolk, var Aabenraa den af de slesvigske Byer, der mødte med det mindste Antal. ${ }^{3}$ ) Handelslivet har vel ogsaa været ret ubetydeligt. Der maa dog have været drevet en vis Kornhandel med Kongeriget, idet Aabenraaerne i 1540 anmodede om at faa ophævet Forbudet imod Opkøb af Korn nord for Kongeaaen. Kansler Johan Friis fraraadede det imidlertid under Henvisning til, at Aabenraa og Flensborg kunde forsyne sig med Korn fra Als og Erø. ${ }^{4}$ ) Mens Tønder omkring Aar 1600 oplevede en Blomstringstid, var Aabenraa stadig den lille stille By, hvor Livet gik sin daglig vante Gang.

Tidens Storhandel, Studehandelen, gik uden om det afsides og fra Omegnen vanskeligt tilgængelige Aabenraa. Der foregik kun ringe Handel med Stude fra Aabenraa Ladegaard og det nærmeste Opland.5) Gang paa Gang klagede Aabenraas Bystyre over Landboernes Overtrædelser af Købstadtvangen. Især Varnæsboerne havde for Vane at søge til Sønderborg med deres Stude. ${ }^{5}$ )

Søhandelen og Skibsfarten var ogsaa ringe. Skibbroen var i en elendig Forfatning. I et Bønskrift til Hertugen anmodede Byen i 1606 om at faa udvist Tømmer til dens Istandsættelse,

2) Sønderjydsk Maanedsskrift 1948, S. 134-136 (N. Black Hansen).

3) Sejdelin: Diplomatarium Flensborgense 1545 17./3.

4) Smstds. 1540 25./12.

i) Se min Afhandling om Studehandelen i 1600-Tallet (Jyske Samlinger 1948, S. 139 ff).

6) RA Gotiorpske Arkiv. Acta A XX 2684 (afl. fra Kiel). 
ligesom man haabede, at Hertugen vilde tænke paa Byen ved Udskibning af Korn og Indførsel af Tømmer, Kalk og deslige, saaledes som det var sket før og endnu kunde ske. ${ }^{7}$ ) Byens Borgmester Claus Esmarch, der blev myrdet i 1610, indlagde sig stor Fortjeneste af Byen ved at faa den nye Skibbro anlagt, en Forbedring, der fik den største Betydning for Skibsfarten.

En Maaneds Tid efter Mordet paa Borgmesteren blev Aabenraa imidlertid ramt af vel den frygteligste Ulykke i Byens $\mathrm{Hi}-$ storie. ${ }^{8}$ ) En Baadebygger og hans Medhjælper var beskæftiget med Skibstømrerarbejde ude paa den nye Skibbro, hvortil de brugte aaben Ild for at holde Tjæren flydende. Paa Grund af Elæsten og Folkenes Uforsigtighed fængede Ilden imidlertid pludselig i det brændbare Stof og i Løbet af kort Tid stod store Dele af Byen i Flammer. Der blev sat en Indsamling i Gang til Fordel for den haardt ramte By; blandt de Byer, som gav de nødstedte en hjælpende Haand, var Lübeck, Rostock og Wismar, derr vel var det daværende Aabenraas vigtigste søværts Forbindelser. Byens første Historiker, Claus Møller, nævner da ogsaa i 1635 , at man for 50 Aar siden havde fanget mange Fisk, især Torsk. Indbyggerne nedsaltede flere Skibsladninger Torsk og solgte dem til de tre ovennævnte nordtyske Havnebyer.

Under den for Danmark og navnlig Slesvig saare ulykkelige Kejserkrig opslog Wallenstein en Tid lang i Aaret 1628 sit Hovedkvarter i Aabenraa. Byens fortrinlige Havn i Forbindelse med de store Skove i Omegnen blev et vigtigt Led i hans noget dilettantiske Plan om Oprettelse af en kejserlig-katolsk Østersøflaade. Samme Aar havde han for øvrigt ladet sig udnævne til "General over det oceaniske og baltiske Hav", og lidt senere

7) Smst., samt Adolf Jürgens: Zur schlesw.-holst. Handelsgeschichte des 16. und 17. Jahrhunderts. S. 66 (Abhandlungen z. Verkehrs- und Seegeschichte, Bd. VIII).

8) Fr. Fischer: Om den store Ildebrand i Aabenraa 1610. (Slesvigsike Provindsialefterretninger. Bd. II, S. 215 ff). 
blev han Hertug i Mecklenburg. $\left.{ }^{9}\right)$ Men takket være Begivenhedernes Gang undgik Aabenraa dog denne Skæbne.

2: Sidste Halvdel af det 17. Aarhundrede blev en Tid af overordentlig stor Betydning for Aabenraas økonomiske Udvikling. Overalt i Europa var Enevælden blevet det fyrstelige Statsideal. I Danmark blev den indført ved Statsomvæltningen i 1660, og selv om man ikke kan tale om en formel Indførelse af Enevælden i Slesvig, blev den dog den faktiske Statsform baade i den kongelige og hertugelige Del.

Inden for den enkelte Fyrstes fast afgrænsede Omraade søgte man at gennemfore Tidens økonomiske System, det, Eftertiden har kaldt Merkantilismen. Idet man ønskede at skaffe sig Raadighed over større Indtægter for at opnaa større Magt, søgte man ved stærke Statsindgreb at fremme Næringslivet inden for Statens Omraade. I Særdeleshed kom denne Politik Byerne til Gode, idet det gjaldt om saa vidt muligt at skabe en hjemlig Industri og fremme Byernes Handel og Søfart, da disse Erhverv jo i særlig Grad var egnede til at trække Penge til Landet. Fyrsterne søgte derfor ved forskellige Forordninger at fremme disse Erhverv, og kunde dette ske paa fremmede Undersaatters Bekostning, regnede man det først rigtig for en Vinding.

Et af de krasseste Eksempler paa merkantilistiske Synspunkter træffer vi en Betænkning af 15. 2. 1673 fra Kommercekollegiet i København til Kongen. De gottorpske Undersaatter i Vestslesvig, der hidtil havde været ligestillede med Kongens egne Undersaatter, havde indsendt en Klage over, at de ved en ny dansk-norsk Toldrulle af 1672 var blevet udsat for ulige Behandling. I Betænkningen gjorde Kommercekollegiet gældende, at Klagen var ,et u-fejlbarligt argument, at Eders Kongl. Ma: Undersaaters Nehring derved sig forbedrit, huoraf

") C. O. Bøggild Andersen: Chr. IV.s Tidsalder. (Schultz Danmarks Historie. Bd. III. S. 92). 
vi och Gud schee loff, god effterretning hafuer. Och siufnis u-feilbahr, at dersom Eders Mayst: udi dend allernaadigste resolution vil forblifue, som nu derom er ordinerit, och saaledis sine egene Undersaatter til nogen nehringsmiddel hielpe, at io disse Eiderstedsche och Nordstrandische med tiden maa forgaae och afftage, och de enten blifue forpligtedt at fløtte till Eders Mayts: Steder, eller Sine schibsrumme did henselge, huorfore vi Allerunderdanigst forhaaber, att Eders Kongl. Ma:" ikke vil efterkomme bemeldte Klage. ${ }^{10}$ )

Uligheden mellem de kongelige og hertugelige Undersaatter vedblev da ogsaa at bestaa. Ligesom Kongen saaledes begunstigede sine Undersaatter, søgte Hertugen imidlertid ogsaa at fremme Næringslivet $\mathrm{i}$ sine Byer ved at give dem Eneret paa Handelen i de gottorpske Omraader.

Gennem hele det 16. og 17. Aarhundrede var Flensborg den slesvigske Østkysts altoverskyggende Handelsby. Aabenraaskipperne formaaede ikke at klare sig i Konkurrencen med denne kongelige By, der besad Toldfrihed i alle Kongens Lande og navnlig drev en udstrakt Handel paa Norge. ")

Med Rette kunde da Caspar Danchwerth i sin „Landesbeschreibung“, der udkom i Aaret 1652, udtale, at Skibsfarten og Næringen til Søs ikke var særlig stor i Aabenraa, men dog blev bedre fra Aar til Aar. Som det nordlige gottorpske Omraades eneste Østersøhavn fik Aabenraa nu med den enevældige Statsopfattelses Sejr sin store Chance.

Allerede tidligere havde Tønder sædvanligvis haft Aabenraa som Transithavn for Varer fra Østersølandene. I 1620 var der Strid mellem de to Byer, men Hertugen fik den bilagt, saaledes at Tønder fortsat kunde benytte Aabenraa Havn mod at betale de sædvanlige Told- og Bropenge og mod i første Række at

10) RA. T.K.I.A. B. 48. Relationes von dem Policey- u. CommerceCollegio. 1673-74, 1703-30; « Sønderjyllands Historie*. Bd. III. S. 279 (H. Hjelholt).

11) Maria Rasmussen: Die Geschichte des Handels Flensburgs bis gegen 1700 . 
unde Aabenraaskipperne al den Fragtfart, disse kunde overkomme at besørge. ${ }^{12}$ ) I 1711 onskede Slesvig Bys Borgere, at deres By skulde forsyne Husum og Frederiksstad med Varer fra Østersølandene; hidtil havde det kongelige Flensborg sørget for Varer til disse Byer. ${ }^{13}$ ) Paa samme Maade tilrev Aabenraa sig med Hertugens Velvilje lidt efter lidt den overvejende Del af Forsyningen af det nordlige gottorpske Omraade. I Modsætning til Slesvig By var Aabenraa fra Naturens Haand begunstiget med en udmærket Havn, der gjorde det lettere for dens Borgere at tage denne Opgave op.

Hidtil var det ofte hændt, at Aabenraaskippere ikke alene sejlede i Fragtfart for Flensborg, men endogsaa flyttede til Byen og lod sig indskrive som Borgere dær. Aabenraaborgerne indsendte derfor en Klage til Hertugen, fordi Skibe, der blev bygget i Aabenraa, sjældent kom til at sejle for Hjembyen, men ret hurtigt blev solgt til Nabobyerne, af hvilke naturligvis den kongelige, privilegerede By Flensborg - skønt den ikke specielt nævnes - var den farligste. Sønderborg, der i 1668 var blevet kongelig $\mathrm{By}$, synes at have haft tilstrækkeligt Opland $\mathrm{i}$ det rige Als, Sundeved og Ærø. Haderslevs daarlige Indsejlingsforhold hindrede derimod denne By ligesom Slesvig By i rigtig at gøre sig gældende.

Hertug Christian Albrechts Svar paa ovennævnte Klage blev da ogsaa en tydelig Begunstigelse af hans egen By. Han forordnede nemlig, at „i Fald nye i Vor Stad Apenrade byggede Skibe straks sælges, skal der for hver Last erlægges Os, Borgmester og Raad og dærværende Commune fire Rdl., men naar saadanne Skibe have sejlet eet Aar ved Staden og derpaa sælges, af hver Last tre Rdl. Naar der er faret med dem to Aar for Salget, erlægges af hver Last to Rdl. og endelig, naar saadanne ere brugte til Søs tre Aar ved Staden, af hver Last een

12) Ludwig Andresen: Acta Tunderensia. (Zeitschrift f. schl.-holst.lauensbg. Gesch. Bd. 39).

1s) Sønderjyllands Historie. Bd. III. S. 280. (H. Hjelholt). 
Rdl. og heraf Os Halvparten, mens det øvrige skal hjemfalde og beregnes til Staden". ${ }^{14}$ )

I de sidste Aartier af 1600-Tallet ser vi Aabenraas Skibsfart i stadig Vækst, selv om Flensborg i hele Tidsrummet op til Nutiden holder sin Position som Slesvigs førende Handels- og Skibsfartsby.

Begunstiget af de krigeriske Forviklinger i Vesteuropa lægger Norge for ovrigt samtidigt Grunden til en hurtig Udvikling af den nationale Skibsfart. ${ }^{15}$ )

Aabenraas vigtigste Handelsforbindelser før Midten af 1600'Tallet havde som nævnt været de tyske Østersøbyer Lübeck, Rostock og Wismar; nu bliver Sverige langt den betydeligste Handelsforbindelse. Mens Kongens Flensborgere havde Norge som vigtigste Handelsomraade ${ }^{16}$ ), søgte de hertugelige Aabenraaskippere i overvejende Grad til Sverige. Ret bemærkelsesværdigt, eftersom det lille gottorpske Hertugdømme siden Svenskekrigene i Midten af 1600-Tallet næsten ganske koordinerede sin Udenrigspolitik med den svenske Stormagts.

Sverige havde navnlig een Vare, som det for største Delen skovfattige Slesvig havde stor Brug for, nemlig Tømmer og Træprodukter i det hele taget. Menneskets hensynsløse og uforstandige Hugst gennem Aarhundreder havde tyndet slemt ud i de tidligere betydelige slesvigske Skovomraader. ${ }^{17}$ ) Skønt det i hele det 16. Aarhundrede havde været forbudt at bygge Bulhuse, fordi de slugte saa uforholdsmæssig store Mængder af Tømmer, ${ }^{1 \times}$ ) fortsatte Bønderne dog længe med denne Trafik. Og endnu værre gik det ud over Skovene i de store Krigsperioder i det 17. Aarhun-

14) Aktstykkerne er i Oversættelse aftrykt i H. Schlaikier: Aabenraa Søfarts Historie. S. 7-9.

15) Alb. Olsen: Danmark-Norge i det 18. Aarhundrede. S. 45.

16) Siden 1694 n $\varnothing \mathrm{d}$ det gottorpske Hertugd $\varnothing \mathrm{mmes}$ Skippere for $\phi \mathrm{vrigt}$ samme Privilegier som de hollandske i det nordenfjeldske Norge. (LA. Aab. Byarkiv. Sager vedrørende Told og Toldvæsen 1609-1868).

17) H. Hejselbjerg Paulsen: Landskabsstudier. Ridrag til det nordslesvigske Kulturlandskabs Udviklinghistorie. (Jyske Samlinger 5. Rk. 5. Bd. S. $196 \mathrm{ff}$.).

18) R. Mejborg: Nordiske Bøndergaaarde. Bd. I. S. 213. 
drede. Ikke blot Fjenden rekvirerede store Mængder Tømmer, men ogsaa den stedlige Befolkning benyttede sig af Lejligheden til at gøre Hugst i Skovene og til for egen Regning at sælge Tømmer. Den 5. 1. 1678 stod derfor ikke færre end 51 Aabenraaborgere anklaget for ulovlig Træhugst $\mathrm{i}$ de hertugelige Skove. ${ }^{{ }^{19}}$ )

Tømmer og Træprodukter maatte derfor indføres. Det lykkedes hurtigt Aabenraa at faa det meste af Nord- og Vestslesvig til Opland for sin Tømmerhandel. Allerede 1653 nævner saaledes Præsten i Hviding ved Ribe, at han har hentet Tømmer til sin Præstegaard i Aabenraa. ${ }^{20}$ )

Fra 1669 blev der i Aabenraa ligesom i de andre gottorpske Byer opkrævet en Licenttold, en Afgift af al Ind- og Udførsel. Aabenraa Amtsregnskaber indeholder for de følgende Aar ret udførlige Opgørelser over Opkrævningen af denne Licentafgift, samt af Bytolden. De er bevaret fuldstændigt fra Aarene 166975, 1682, 1690-1706 og 1708. Ved Hjælp af disse har det som den følgende Skildring skulde vise - været muligt at faa et Billede af hine Tiders okonomiske Liv i og omkring Aabenraa. Regeringens aarlige Indtægter af Licenten giver et Indtryk af Handelsomsætningens Størrelse fra Aar til Aar. Aarene omkring 1690 skulde efter dette have været særdeles gunstige. Omkring Aar 1700 var man derimod nede i en Bølgedal med et tydeligt Lavpunkt i det nævnte Aar, fremkaldt af den kortvarige Krigstilstand mellem Konge og Hertug. Umiddelbart før Elleveaarskrigen i 1709 tog sin Begyndelse, stod Handelsomsætningen igen paa Højde med Aarene omkring 1690 og endda med Tendens til yderligere Stigning.

3: Aar efter Aar, gerne tidlig i Foraaret — som oftest i Marts og April — stod Aabenraaskibene ud af Fjorden for i Maj, Juni og de øvrige Sommermaaneder at vende hjem med Fragt. Pro-

19) RA. Matthiessens Samlinger. Pk. 17. Mandat fra Hertug Chr. Albrecht 1677 4./12. til Aabenraa By.

20) Carsten Petersen: Slesvigske Præstegaarde. (Sønderjydske Aarbøger 1946. S. 267). 
blemet var for Aabenraaskipperne - som for den Tids Skippere i det hele taget - saa vidt det lod sig gøre at undgaa Sejlads med Ballast. Dette lykkedes dog langtfra altid. Næsten hvert Aar maatte over Halvdelen af de udgaaende Skibe sejle i Ballast. Det var nemlig kun faa Varer, Aabenraa var i Stand til at udføre over sin Havn. Fra Højer kom der aarlig en hel Del Østers, som gik til forskellige Østersøbyer, bl. a. var ogsaa den gottorpske Familie, der i Aarene omkring 1700 opholdt sig i Stockholm, Storaftager af denne Vare. Østershandelen var dog ikke uden Risiko. Skipper Caspar Koch, der i 1712 undervejs. til Stockholm fik Modvind, opdagede ved Aabningen af Tønderne, at 3000 Stk. (= 5 Tdr.) var raadne. Men endnu i Aaret 1720 ses det, at Aabenraa eksporterede $367 \mathrm{Td}$., hvoraf en Del nu gik til det ny grundlagte Skt. Petersburg. Selv havde Aabenraa for øvrigt en lignende Vare $\mathrm{i}$ sin Fjord; nemlig Muslinger. ${ }^{21}$ ) Indtil helt op $i$ det 19. Aarhundrede har man avlet disse ved Fjorden. 1712 ses det, at Byen havde en Mand ansat til at passe denne Avl.

Brænde fra de omliggende Skove var man altid sikker paa at kunne faa afsat i København, hvorfor man aarlig ser dette udført. En anden Vare, der paa Grund af sin Vægt havde større Interesse som Eksportvare, var Mursten fra Teglværkerne ved Aabenraa Fjord, af hvilke det i 1642 ved Jørgensgaard grundlagte og den saakaldte nye Teglgaard ved Skelbæk fra omkring 1700 var de betydeligste. Ogsaa før denne Tid fandtes der Teglværker ved Aabenraa, f. Eks. Teglgaarden paa det nuværende Klinkbjerg. I 1619 onskede man saaledes paa Koldinghus 10.000 Mursten fra Aabenraa. ${ }^{22}$ ) Betegnende nok formaaede Aabenraa Teglværkerne imidlertid endnu ikke at fabrikere Tagsten i større Mængder. De maatte i Tiden før den Store nordiske Krig indføres, først og fremmest fra Lübeck, ligesom ogsaa Teglværkerne ved Flensborg Fjord allerede da havde stor Betydning.

21) Heimatblätter aus Nordschleswig 1940, S. $98 \mathrm{ff}$.

22) Kancelliets Brevbøger 1619 13./4. 
Aabenraaskippernes vigtigste Fortjeneste laa som nævnt $i$ at forsyne det meste af Nord- og Vestslesvig med Skovbrugsprodukter samt forskellige Bjergværksprodukter, som man fremskaffede fra det fra Naturens Haand rigt udstyrede Sverige. Hvert Aar kom Aabenraaskibene hjem fra Västervik i Småland, fra Visby paa Gotland og fra mange andre svenske Havnepladser med en Last, bestaaende af Brædder, Balkuner ${ }^{23}$ ), Bjælker, Deler, Sparrer, Lægter o. s. v. Desuden fik man i Sverige Tjære, Beg, Kalk, Jern, Kobber samt Fliser og Gravsten eller Trappesten. Ogsaa fra Norge hentedes jævnligt forskellige Tømmersorter, betydeligst blandt disse var Lægter, undertiden lidt Fisk og Tran. I flere Aar indførtes der dog intet eller kun ganske lidt fra Norge, og Indførselen besørgedes for øvrigt i ikke ringe Grad af Læsøskippere, der paa deres Skuder bragte Tømmer til Kattegat- og Bælthavnene. Der kunde paa en Sommer komme op til 10 Skuder fra Læsø, men efter 1700 dalede dette Antal dog ganske betydeligt for til sidst helt at ophøre.

Af Landbrugsprodukter foregik der gennem Aarene en ret betydelig Indførsel af Hør, Hamp og Blaar fra de baltiske Lande, specielt fra den store Handelsby Riga samt fra Østersøkystens nordtyske Havnebyer. Noget Humle kom der ogsaa til Aabenraa ad Søvejen, skønt Humledyrkningen var meget udbredt $\mathrm{i}$ hine Tiders Aabenraa. Hver Grundbesidder havde en Humlegaard. Hele 1600-Tallet igennem betalte Aabenraaborgerne en aarlig Afgift af 199 Skpd. hjemmeavlet Humle. ${ }^{24}$ ) Langt det meste af den Humle, der i hine Aar anvendtes i Slesvig, tilførtes dog ad Landevejene, ligesom ogsaa næsten alle Industri- og Kolonialvarer samt lignende Produkter Syd fra blev bragt herop af som oftest tyske Handelsmænd eller indførtes via Havnene Højer og Ballum. ${ }^{2 \pi}$ )

$\left.{ }^{23}\right)$ Balkun, hollandsk Udtryk, i Sømandssprog Barkun, betyder lang Bjælke, specielt til Skibsbygning. Deler er Tidens gængse Betegnelse for brede Brædder. (Se Mensing: Schlesw.-holst. Wörterbuch).

24) Aab. Amtsregnskaber i Rigsarkivet. (Skpd=Skippund).

25) Saaledes f. Eks. 1698 23./6. Varer fra Holland via Ballum; 1706 20./6., 1708 4./8. via Højer. 
Jævnlig indførtes der ogsaa fra det tyske Østersøomraade og fra de danske Øer en Del Korn, som enten er blevet konsumeret i selve Hertugdømmet eller ogsaa reeksporteret via den slesvigske Vestkyst eller med Aabenraaskibe. For øvrigt synes Datidens Slesvig ikke at have haft noget synderligt Kornoverskud tii Eksport. ${ }^{28}$ ) Ligesom Humle indførtes der ogsaa jævnligt en Del Malt. Aabenraa var fra gammel Tid kendt viden om for sit Ø1, ifølge Claus Møller kaldet „Kükelhaen“. I 1621 klagede Forgerne dog over, at Aabenraaøllet udkonkurreredes ved Indførselen af det endnu bedre Wismarøl, som solgtes i Tøndevis til Bryllupper i Byen og dens Opland. Man anmodede derfor om Forbud imod Indforsel af Wismarøl.

Fra de tyske Egne ser vi endvidere en ret betydelig søværts Indførsel til Aabenraa af Lüneburgsk Salt samt af Jern, Staal, Bly og lignende Grovvarer.

Med Havnene i Kongeriget var der i den gottorpske Tid kun ringe Samhandel. Som nævnt gik en Del af Eksportvareme hertil, først og fremmest til København; Indførselen herfra var imidlertid yderst ringe. Det drejede sig i Regelen om Varer som fransk Vin, Brændevin eller ogsaa lidt Kolonialvarer. ${ }^{27}$ )

I Aarene op mod 1700 begyndte Aabenraaskippere imidlertid ogsaa at søge til fjernere Egne. Den 25. 3. 1692 sejlede saaledes Hinrich Frellesen af Sted med Kurs mod Rusland, d. v. s. Kolahalvøens og vel ogsaa Finmarkens Kyst, idet Varerne deroppe fra gerne er Fisk (Stokfisk) eller Tran. Ved en enkelt Lejlighed rævnes for øvrigt mere præcist: „Fischer Eyland und Lapland“, altsaa de norsk-finsk-russiske Grænseegne. I Omraadet Øst for

26) 1714 nævnes, at Byen overhovedet ikke driver den ringeste Handel med Rug, Byg og Havre. (LA. Aab. Byarkiv VII 78-79. Priser paa Korn og andre Levnedsmidler). Faa en Opfordring til at aflevere Korn i 1730 svarede Magistraten: "Da denne By intet Landbrug har, maa Stedets Kornbehov tilføres fra Landet eller ad Søvejen $\alpha$. (LA. Aab. Byarkiv VII 77. 2.). Als og Sundeved havde derimod Kornudf $\varnothing$ rsel.

${ }^{27}$ ) Vinen var ofte bestemt til fornemme Personer i Omegnen, saaledes var i 1694 af Indf $\varnothing$ rselen fra København Vinen bestemt til f $\varnothing 1-$ gende: 26./8. til Grevinde Schack, 23./10. til Amtforvalteren i Haderslev, Pastor Wilhadus Fabricius i L $\varnothing j$ t, samt Borgmesteren i Flensborg. 
Vardø herskede der nemlig Frihandel, mens Bergen og Trondheim lige siden 1591 havde Monopolrettigheder paa den øvrige norske Kyst. ${ }^{2 \mathrm{~g}}$ ) Først den 24. 10. samme Aar vendte Hinrich Frellesen tilbage. Sidste Havn, han havde været i, var Flensborg. Som saa ofte senere har han altsaa været befragtet af Flensborgkøbmænd. Aabenraaskipperne har vel i det hele taget begyndt deres Langfarter som Fragtfarere for Flensborgkøbmænd. ${ }^{29}$ ) Naar Flensborg optræder i Regnskaberne fra Aabenraa Havn er det da ogsaa, fordi Aabenraaskippere, der har sejlet for denne By, herfra har bragt noget af Lasten med til deres Hjemby. Nævnte Ruslandsfart er derfor ganske givet ikke den første, der er foretaget af Aabenraaskippere.

Den 1. 9. 1695 ses det første Gang, at et Aabenraaskib, ført af Skipper Hans Brodersen, bringer en Ladning fra den russiske Ishavskyst direkte til Hjembyen. En saadan Langfart var imidlertid økonomisk set et risikabelt Foretagende. Skipper Frelle Christensen, som 12. 8. 1697 og 24. 8. 1698 vendte hjem fra Rusland med gode Ladninger, kom saaledes 12. 8. 1699 tilbage fra en Ruslandsfart uden Last, da der, som det nævnes, ingen Fisk var at faa dær. Han synes dog ikke at have ladet sig afskrække, idet han de følgende Aar (1700 6./9., 1701 20./9.) atter bragte Varer hjem fra Ishavskysten.

Aarene herefter nævnes han ikke i Regnskaberne. Forklaringen faar vi imidlertid den 20.5. 1705, idet han paa denne Dato vendte hjem med Last fra Newcastle efter i 3 Aar at have været "detineret" i Zeeland ved den hollandske Kyst som Offer for Krigsbegivenhederne i Vesteuropa. Flere norske Skibe led for øvrigt samme Skæbne i disse Aar. ${ }^{30}$ ) Uforknyt sejlede han dog allerede den 1. 7. samme Aar paany til Newcastle efter

28) Maria Rasmussen: Die Geschichte des Handels Flensburgs gegen 1700. Denne Forordning var en Følge af Kristoffer Walkendorfs Virke til Gavn for den norske Handel.

29) Her har vi vel ogsaa en af Aarsagerne til det overordentlig ringe Antal Aabenraaskibe, der næunes i $\emptyset$ resundstoldregnskaberne.

30) RA. T.K.I.A. B. 48. Relationes von dem Policey- und CommerceCollegio $1673-74,1703-30$. 
Last, hvorfra han vendte tilbage den 12. 8. Dog ikke nok med det. Allerede den 30. 9. stod hans Skib atter ud af Fjorden, denne Gang med Riga som Maal. Herfra kom han dog den 5. 12. tilbage uden Last, da der, som det nævnes, intet var at faa dær. Krigsbegivenhederne stillede sig altsaa ogsaa hindrende i Vejen for Aabenraaskipperens fredelige Handel med Østeuropa.

Fra Aaret 1705 slog Frelle Christensen sig imidlertid paa Frankrigshandelen. Den 21. 4. nævnte Aar forlod han Aabenraa med sit Skib paa 60 Laster, medførende 250 Tylt Brædder og 2 Fade Talg. Forst den 12. 9. samme Aar vendte han tilbage fra Lokaliteten St. Martin i Frankrig med en Last bestaaende af fransk Vin, Brændevin, Vineddike og Sirup. Et Par Maaneder senere (22./11.) vendte han hjem med en stor Last fra Riga. Den 6. 3. 1708 satte samme Skipper igen Kurs mod Frankrig med 250 Tylt Brædder, som han den 24. 10. 1707 var kommet hjem med fra Västervik. Den 29. 8. 1708 vendte han tilbage fra Frankrig med en rig Ladning Salt og Vin. Endnu den 12. 12. samme Aar kom han ind i Havnen med forskellige Varer fra Västervik, bl. a. en Ladning Brædder, bestemt til Udførsel, hvorfor der ikke skulde betales Licent af dem. Han har saaledes været en af de første Aabenraaskippere, der forstod at undgaa at sejle den ene Vej i Ballast, idet han hver Gang tog en Ladning Trælast, som han i det foregaaende Aars sidste Efteraarsmaaneder havde hentet i Sverige, med sig til Vesteuropa som Salgsvare.

$\mathrm{Da}$ Regnskaberne ikke er bevaret længere, er vi desværre ikke i Stand til yderligere at følge denne driftige Aabenraaskipper, der har været med til at grundlægge sin Bys senere betydelige Søhandel.

Saaledes som Frelle Christensen havde løst Ballastproblemet med Hensyn til Frankrigshandelen, indrettedes efterhaanden ogsaa Handelen paa England. Oftest var det svensk Tømmer, hentet om Efteraaret, der det følgende Aar om Foraaret sejledes til det skovfattige England eller Irland. Fra England, 
specielt Havnene Newcastle og Liverpool, skaffede Aabenraaerne sig engelsk Salt, Stenkul, Bly eller lignende, som de videresendte til forskellige Østersøhavne. ${ }^{31}$ ) Undertiden sejlede de Korn til Norge fra de danske Øer, specielt Fyn, samt fra Als og Fehmarn. Fra Norge bragte de Tømmer til England og kom saa derfra tilbage med engelske Varer.

Handelen paa England begyndte den foretagsomme Skipper Hinrich Frellesen - kendt fra den tidlige Ruslandsfart - idet han den 24. 9. 1696 bragte den første Ladning hjem herfra. Allerede den 14. 3. 1693 indledede han dog den vestgaaende Handel ved at tage Kursen mod Holland, medførende Flæsk, \#rter og Gryn. Den 31. 8. meldte han sig hjem fra denne Tur og opgav Flensborg som den Havn, han sidst havde besøgt. Han har vel stadig været befragtet af Flensborgkøbmænd. Skippere fra Aabenraa besørgede nemlig ogsaa en Del af Trafikken mellem Sverige og Flensborg. En enkelt af de større Skippere, Christian Frellesen Frees, sejlede saaledes i Aarene umiddelbart efter 1700 for baade Haderslev- og Flensborgkøbmænd. Disse Farter indbragte ham saa meget, at han i 1707 kunde tage et nyt Skib i Brug paa 60 Læster. Det var bygget i Aabenraa. ${ }^{32}$ ) Tidligere havde Aabenraaerne ofte ladet deres Skibe bygge i Eckernførde eller Neustadt (Nienstadt) i Holsten tæt ved Lübeck.

Tønder forsynedes til Stadighed med Varer fra Østersøomraadet via Aabenraa. Aarligt indførtes der licentfrit en ret betydelig Varemængde, bestemt for denne By. 1705, 1706 og 1708

31) 1708 25./9. sejlede saaledes Skipper Frelle Clausen til Riga med fransk Salt, som Frelle Christensen var vendt hjem med, og 28./9. sejlede en alsisk Skipper med engelsk Salt til Rostock, f $\varnothing$ rt til Aabenraa af Skipper Michael Rolfsen.

32) Chr. Frellesen Frees er omtalt i Sønderjydsk Maanedsskrift 16. Aarg. S. 221. (M. Michelsen: Aabenraa Bys Søfart). Der gives her atter et Vidnesbyrd om en Aabenraaskippers Sejlrute: Kork og Brændevin fra Flensborg og Bogense til Trondheim, derfra videre med Trælast til Dublin, herfra i Ballast til Liverpool eller Newcastle for at laste Salt til Haderslev. - Skipper Svenne Truelsens Stockholmsfærd i 1693, der nævnes i samme Afhandling, var derimod en ganske almindelig Foreteelse. Han vendte for $\phi v r i g t$ tilbage derfra 27./7. nævnte Aar. 
indførtes der desuden Ladninger, bestemt til den kendte Købmand Michael Jovers i Husum.

4: Regnskaberne over Bytolden for de samme Aar som for Licentregnskabernes Vedkommende giver os et Billede af Aabenraas økonomiske Forbindelser med sit Opland i Aarene omkring 1700. Hovedgrundlaget for denne Handel dannede de Varer, som Søfarten skaffede til Byen: Tømmer, Tjære, Kalk, Jern o. s. v. Det er interessant at se det store Omraade, som fik en større eller mindre Del af Tømmerforsyningen fra Aabenraa. Oplandet bredte sig vifteformet ud fra Byen og strakte sig helt ud til den slesvigske Vestkyst lige fra Bredsted i Syd til Ribe i Nord. De skovfattigste Egne var helt naturligt de største Konsumenter. Foruden Herrederne under Aabenraa Amt optraadte navnlig Slogs, Kær, Tønder, Lø, Nr. Rangstrup og Hviding Herreder som Hovedaftagere. Bemærkelsesværdig er endvidere den ikke ringe Del, som gik til Marskherrederne Syd for den nuværende Grænse. Samhandelen med disse Egne beroede imidlertid ogsaa paa et andet Forhold. Marskbønderne herfra, ja helt nede fra Eidersted og Stapelholm samt fra de udenfor liggende Øer, saaledes Før, Pelworm etc., opkøbte nemlig Heste og Stude i Nordslesvig til Opfedning paa deres frodige Græsarealer, før de videresolgte dem til Nordvesttyskland og Holland. Det skete for Aabenraas Vedkommende hvert Aar navnlig i Dagene 9.-11. Juli og 12.-14. Oktober. ${ }^{33}$ ) Ved samme Lejlighed førte de gerne noget Tømmer med sig til deres skovløse Hjemegn.

Ogsaa andre end Marskbønderne forefindes i Regnskaberne som Kvæghandlere. I Dagene 8.-11. April, 20.-22. Maj, 6.-7. Juni og 11.-18. September ses saaledes adskillige Bønder fra det nordøstlige Slesvig, navnlig Løjt og Næsset, erlægge Bytold for Stude og Heste. Blandt dem er der Folk fra de store Frigaarde paa Næsset. 9. April og 9. September afholdtes fra gam-

${ }^{{ }^{3}}$ ) Jyske Samlinger 1948, S. 139 ff. 
mel Tid de over hele Landsdelen kendte Markeder i Kliplev. I andre af de nævnte Tidsrum har der været Markedsdage i selve Aabenraa. ${ }^{34}$ ) Haderslev, der i Modsætning til Aabenraa laa ved Oksevejen, den direkte nord-sydgaaende Færdselsaare, havde en langt mere betydelig Stude- og Hestehandel end Aabenraa. ${ }^{3.5}$ ) Det var først og fremmest de fra fremmede Kyster ad Søvejen indbragte Varer, der gav Grundlaget for Aabenraas Samhandel med det meste af Nord- og Vestslesvig. For Datidens Aabenraaborgere gav det gamle Ord, „Navigare necesse est“, god Mening.

5: I Aaret 1709 tilføjedes der i Slaget ved Poltava den svenske Stormagt et Knæk, som den ikke siden formaaede at rejse sig. efter. Den danske Stat kunde derfor nu trygt genoptage $\sin \mathrm{i}$ Aaret 1700 mislykkede Krig med Sverige. For den gottorpske Stat betød denne Situation imidlertid alt andet end lyse Udsigter, selv om det lykkedes den at holde sig uden for Krigsbegivenhederne i Aarene fra 1709 til 1713. For den Del af de gottorpske Undersaatter, som beskæftigede sig med Udenrigshandel, blev disse faa Aar som neutralt Omraade blandt lutter krigsførende Magter vel den gunstigste politiske Konstellation, man nogensinde havde oplevet.

Aabenraa Bys Søfart gennemgik da ogsaa i disse fire Aar en rivende Udvikling. De Handelsforbindelser med fjerne Egne i Vesteuropa, som netop var blevet knyttet, udnyttedes nu i udstrakt Grad. 1705 var Byens samlede Handelsflaade paa 779 I.æster. 1710 var den derimod steget til 1109 Læster. ${ }^{36}$ ) Byens

34) 1666 tildelte Hertug Chr. Albrecht Aabenraa 3 Markedsdage tre Gange aarligt, nemlig 12., 13. og 14. April, 3 Dage omkring Margarethe Dag (13. Juli), samt 3 Dage omkring Gallus-Dag (16. Oktober). 1723 flyttedes de sidste til hhv. Maria Magdalena (22. Juli) og Severinus (23. Oktober). (RA. T.K.I.A. D. 63. Aabenraa By. Økonomiske Sager. Handels- og Søfartssager 1723-1847).

35) Th. O. Achelis: Aus der Geschichte des jütischen Ochsenhandels (Zeitschrift Bd. 60); samme: Haderslev i gamle Dage II. 81 ff.

3\%) L.A. Aab. Byarkiv. Skibbroregnskaber. M. Michelsen: Aabenraa Bys Søfart. (Sdrj. Maanedsskrift 16. Aarg.) opgiver for Aaret 1713 en samlet Handelstonnage paa 1088 Læster. 
Indbyggerantal er for Aaret 1709 opgjort til 1253 Personer $^{37}$ ); heri er dog ikke medregnet Kolstrup og Slotsgade, som hørte under Amtet. Ikke desto mindre var Tonnagen ganske betydelig i Forhold til Folketallet. De sidste Aar under gottorpsk Styre har været en lykkelig Tid for Aabenraa. Intet Under, at et „gottorpsk Sindelag“ synes at have været raadende i Byen ogsaa i nogen Tid efter Inkorporationen. Som neutrale sejlede de nogenlunde uantastet af de krigsførende, forsynede med et hertugeligt Søpas, hvorfor de i disse Aar endogsaa blev befragtet af Amsterdamkøbmænd. Efter et Udkast i Byarkivet har et saadant Søpas haft følgende Ordlyd: „Vi Borgmester og Raad for Byen Aabenraa, beliggende ved Østersøen i det suveræne Hertugdømme Slesvig i Sønderivlland [und $\mathrm{zu}$ dem dänischen Reiche nicht gehörig] kundgør, at N. N. i denne By er edssvoren Borger og Undersaat og ikke med Edspligter undergivet anden Herre end ene og alene det højfyrstelige Hus Holsten-Gottorp, og at ikke paa nogen Maade nogen danske eller andre Potentater, som er impliceret $i$ den nordiske Krig og er Kongen af Sveriges Fjender, har Del i denne Galiote ${ }^{34}$ ), og endvidere, at Ladningen ikke bestaar af Kontrabandevarer." I Udkastet til dette Skibspas, der saa tydelig er udfærdiget med svenske Myndigheder for $\varnothing$ je, er imidlertid den i Klammerne staaende Sætning ,und zu dem dänischen Reiche nicht gehörig“ overstreget. Ved en anden Lejlighed, da Franskmændene havde beslaglagt nogle Aabenraaskibe, angaves disses Tilhørsforhold paa følgende Vis: ,aus dieser Stadt, welche in dem Souverainen und neutralen

37) L. A. Aab. Byarkiv VII 77. 1. Om Oprettelsen af et Kornmagasin i Byen 1709 .

3*) Fart $\varnothing j e r$ over 30 Læster kaldes gerne "Skib i Regnskaberne; Galiot og Krayert er forskellige mindre Skibstyper. Senere er der aabenbart ogsaa bygget større Galioter. Betegnelsen Skude bærer derimod kun faa Aabenraaskibe $i$ det behandlede Tidsrum. Se nærmere Skibslisterne i H. Schlaikier: Aabenraa Søfarts Historie. S. $137 \mathrm{ff}$. I Aarene 1706-08 var der 9 Aabenraaskibe over 30 Læster. De ejedes af følgende Skippere: Hinrich Frellesen (65 Lst.), Frelle Christensen (60 Lst.), Chr. Frellesen Frees (60 Lst.), Jacob Sedin (55 Lst.), Knudt Jacobsen (50 Lst.), Jacob Lausen (50 Lst.), Michel Rolfsen (36 Lst.), Nis Krag (36 Lst.) og Thomas Tordsen (30 Lst.). 
Hertzogthumb Schleswig belegen, und zu dem Römischen Reiche nicht gehöret". Mens man aabenbart har fundet den første Paastand om, at der ingen Samhørighed var med det danske Rige noget vovet og derfor har-udeladt den, har man med fuld Ret kunnet gøre gældende, at man ingen Tilknytning havde til Frankrigs Modstander i den spanske Arvefølgekrig: Østrigs Fyrste, den tysk-romerske Kejser. Betegnende for de gottorpske Landes nære Tilknytning til Sverige før Besættelsen i 1713 er det, at det i 1711 i Anledning af Franskmændenes Kapringer meddeltes ikke alene Aabenraa, men ogsaa de andre søfarende Stæder, Eckernförde, Frederiksstad, Husum, Tønning og Tønder, at den svenske Gesandt i Paris, von Cronstrohm, varetog de gottorpske Undersaatters Interesser i Frankrig. ${ }^{39}$ )

Byens førende Købmand, Lorenz Biørnsen, som havde Skibsparter i adskillige Skibe, havde i 1700 faaet fyrstelig Fuldmagt til Udstedelse af Skibspas. Imidlertid rejste der sig i 1703 en hel Del Klager over hans Adfærd, idet han beskyldtes for først at udstede Skibspas til de Skibe, han selv havde Part i og derudover kun til sin egen Omgangskreds, mens han, som det hedder i Klagen, udsatte Udstedelsen af Skibspas til "de gode Folk, som ikke hører til hans Cabale“. Borgmester og Raad overtog derefter Pasudstedelsen.

En Følge af, at Aabenraas Søhandel saaledes blomstrede i hine Aar, mens de kongelige Nabobyers Skibe var udsatte for at blive kapret af Fjenden, var, at en Del Borgere fra disse Byer søgte til Aabenraa for at tage Borgerskab dær.40) Den mest kendte af disse var Christian Kaadt fra Sønderborg, „Pensionair" paa de adelige Godser Skovbølgaard og Rønhavegaard, hvis Ansøgning om at blive Borger i Aabenraa er dateret 1711 16.3. Han ejede de 15/16-dele af Skibet „Haabet“ paa 86 Læster, som hver Sommer sejlede i Fart mellem Holland, Irland, Eng-

39) Dette og den følgende Skildring: LA. Aab. Byarkiv XI 157 d-e. Forskelligt vedrørende Skibsfarten $1713-15$.

40) LA. Aab. Byarkiv. 11. Borgerbreve og Korrespondance vedr. Optagelse i Borgerskabet. 1709-1869. 
land, Skotland og Norge, mens Skipperen, der førte Skibet, havde Resten. Som Pensionær paa Rønhavegaard paa Als havde han tidligere erhvervet sig kongeligt Borgerbrev i Sønderborg, hvorfor Aabenraaborgerne var imod hans Optagelse blandt Byens Borgere. Dette lykkedes ham imidlertid alligevel, og han blev endogsaa indgiftet $\mathrm{i}$ de førende aabenraaske Søfartskredse, idet han blev viet til den foran nævnte Skipper Frelle Christensens Enke, Catharina Margaretha. For øvrigt ejede han stadig nogle Skibe, der sejlede ud fra Sønderborg og hørte med til denne Bys Flaade 1715 og 1717 mistede han saaledes to mindre Galioter, som var hjemmehørende dær. ${ }^{41}$ )

Da Skibene nu var større, blev det mere og mere Regelen, at et Skib ikke ejedes af en enkelt, men af flere Interessenter, som hver havde deres "Skibspart". Et enkelt Skib var saaledes delt mellem følgende: Chr. Kaadt havde $7 / 16$ Skibspart, Jens Kaadt 1/16, Nis Krag 1/16, Anders Jørs 1/16, Jacob Biørnsen 1/16, Christian Hinrich Frellesen 1/16, Hinrich Frellesen 3/16 og Dr. theol. Christian Gottlieb Koch 1/16. Risikoen for de kapitalstærke Folk blev mindre ved at have deres Kapitalanbringelser fordelt i mindre Skibsparter paa en Række Skibe. Men som før nævnt var der ogsaa nogle, der ejede næsten alle Skibsparterne, saa at man kun overlod Skibsføreren en enkelt, hvilket muligvis kunde anspore denne til at faa mere ud af Fragtfarten, idet det jo paa den Tid har været ret ugørligt for en Rheder at kontrollere sine Skippere, naar de var ude paa Langfart. Skibsfartens Betydning for Aabenraaborgerne ogedes tilmed yderligere ved Partsrhederiets Udbredelse. Ikke alene den søfarende Stand, men ogsaa Købmænd, ja, som det ses, f. Eks. ogsaa Byens Provst, var nu Interessenter og havde Skibsparter i den lokale Handelsflaade.

6: Med den danske Konges Besættelse af det gottorpske Om-

41) RA. Krigskancelliet. Indsendte Relationer om lidt Krigsskade. Besvarelser af Overkrigssekretærens Cirkulære af 1721 15./2. 
raade i 1713 kom Aabenraas søfarende Borgere ud for alvorlige Vanskeligheder. Allerede den 14. 3. nævnte Aar kom der en Ordre til Magistraten om at lade Skipperne sejle Magasinkorn fra Randers, Aalborg o. s. v. til Flensborg og Eckernförde. Ordren var underskrevet af Rasmus Finck, Kommandant paa en Orlogsgast, der laa til Ankers ved "Aben Roe“. Magistraten anmodede dog om Fritagelse herfor bl. a. under Henvisning til, at de, der blev tvunget til denne Sejlads i Aaret 1700, endnu ikke havde faaet deres Betaling. Som Følge af, at Aabenraaskibe alligevel blev beslaglagt af den kongelige Flaade, sendte samtlige „negotierende" Borgere og Skippere et Klageskrift til Kongen. De anmodede om Frigivelse af de beslaglagte Skibe og Tilladelse til i Østersøen at sejle med Stadspas, saaledes som det havde været Tilfældet under Krigsbegivenhederne i Aaret 1700. Endvidere kunde de ønske en Bekendtgørelse om, hvorvidt det ,in der Nord- und Westsee" var tilladt dem fortsat at sejle med "højfyrsteligt" Pas. Som Begrundelse for dette udtaltes der, at "denne fattige og miserable Stads ringe og eneste Næring bestod i Skibsfarten", eftersom der ikke længere hørte Jord til Byen..$\left.^{42}\right)$ „Blev derfor Skibsfarten taget fra dem eller hæmmet, vilde det føre dem i den yderste Ruin, og de vilde være ude af Stand til at betale selv de ringeste Skatter. Dog ikke alene Aabenraaeme, men ogsaa de kongelige Undersaatter i Flensborg og Haderslev, ja endog paa Fyn, Sjælland og i Jylland, vilde lide derunder, eftersom det jo var kendt, at det, som disse un-

12) I Skraaen nævnes Aabenraas Græsningsrettigheder i Hostrup, Stubbæk, Aarup, Hessel, Gammelopn $\varnothing$ r, L $\varnothing j t$ og Brundemark. Efterhaanden var denne Ret dog indskrænket til kun at gælde Sønderskoven Syd for Byen. 1704 havde en hertugelig Kommission imidlertid forhøjet Byens Afgift af dette Omraade fra 4 til $40 \mathrm{Rdl}$. aarligt og oven i Købet luftet den Mulighed, at der vilde blive oprettet en hertugelig Ladegaard i S $\varnothing$ nderskov, idet man der mageligt kunde græsse $150 \mathrm{~K} \emptyset \mathrm{er}$. 1721 2./12. efter Inkorporationen besluttede Rentekammeret imidlertid, at Sønderskoven fremtidig skulde tilhøre Byen mod en aarlig Afgift af 20 Rdl. Dette blev hilst med Glæde af Byens Borgerskab og har vel bidraget til at skabe en loyal Følelse mod det nye Styre. (RA. T.K.I.A. B. 160. Afskrifter af Aabenraa og Slesvig Byers Privilegier, indsendte i Henh. til Patent af 15. Maj 1723). 
der Krigen havde tilhandlet sig i Østersøen, for en god Dels Vedkommende var sket ved Hjælp af Aabenraaskibe, da hine jo ikke kunde sejle i Sikkerhed for svenske Kapere. Med kongeligt Pas vilde det gaa Aabenraaskibene paa samme Maade".

Klagen er dog ikke blevet hørt, for den 13.8.1714 kom der til Byen et Brev fra den kongelige Regering, som klagede over, at Aabenraaskipperne trods Krigen stadigvæk handlede med Sverige. Saafremt dette ikke hørte op, truedes de skyldige med Konfiskation. Den 29.8. 1714 udstedtes der endvidere en kongelig Ordre til Marinen om at give frit Lejde til ikke mindre end 48 Aabenraaskibe, som før Brevet af 1714 13./8. var afsejlet til Sverige, men som dog alligevel skulde have Lov til uhindret at vende hjem med deres Last.

Det nævnte Forbud mod Handelen paa Sverige fremkaldte imidlertid Magistratens Klage af 1714 20./10. Skibsfartens enorme Betydning for Byen fremhævedes atter. Handelsflaaden var nu i Neutralitetsaarene vokset saa meget, ,at den-var afhængig af Fragtfart for andre Byer. Til Sverige gik Byens „største og bedste" Skibsfart, idet man dær hentede Tømmer, Lægter, Bjælker, Jernværk, Kalk og Tjære, som blev afsat i Hjembyen eller i Nabobyerne. I England hentede man derimod kun lidt Salt og Stenkul, som der kun var lidt at afsætte af, da hamburgske, lybske og hollandske Skibe nu atter sejlede frit, (nemlig efter den spanske Arvefølgekrigs Afslutning 1713). Landet kunde imidlertid ikke undvære Varerne fra Sverige; et saadant Forbud vilde derfor kun medføre, at man maatte have Varerne gennem Lübeckerne og Hollænderne til dobbelt Pris. Herved vilde baade Aabenraaskipperne, som ikke kunde tjene Fragten, cg Landboerne, der maatte betale Varerne saa meget dyrere, lide haardt. „Man kunde ikke vide, hvorlænge den nordiske Krig vilde vare“, fortsættes der i Skrivelsen, „og Borgernes Kapital blev stadig mindre, hvilket ogsaa vilde ramme Nabobyerne, idet Flensborg, Haderslev, Sønderborg og andre Byer jo udelukkende fik deres svenske Varer saa billigt under den Forud- 
sætning, at Aabenraaskibene havde fri Sejlads. Et fortsat Forbud vilde sluttelig ogsaa medføre, at Byens Told- og Licentafgifter sank, og det vilde være Borgerne umuligt at overkomme Indkvartering og lignende Byrder“. Hvor alvorlig denne Sag overhovedet var for Byens Borgere, kan maaske Slutningen vise: „Derfor falder vi allerunderdanigst Eders Majestæt til Fode og beder Ham tage denne vores allerunderdanigste paatrængende nødvendige Forestilling i allernaadigste Betragtning o. s. v."

Foruden den nye kongelige Øvrighed havde man dog ogsaa den gamle Landsfader at ty til. Fra sit Eksil i Hamburg havde Hertugen nogle Maaneder i Forvejen endnu engang rakt sin By en hjælpende Haand. Den 23.6. 1714 var nemlig Skipper Frelle Clausen blevet kapret af Svenskerne og ført til Göteborg. Hans Rhedere og Interessenter Hermann Frees og Chr. Kaadt gjorde Krav paa, at Skibet blev anset som neutralt Fartøj paa Vej mod neutral Havn, da Besætningen var den højstfyrstelig gottorpske Hertug Carl Friederichs Undersaatter. „De havde troet og troede stadigvæk uagtet den af Kongen til Danmark-Norge foretagne Besættelse af disse højfyrstelige gottorpske Lande, at de ikke kunde anses for at være Sveriges Fjender." Allerede 30. 6. samme Aar sendte Hertugen derfor fra Hamburg en Anmodning til den svenske Regering om at frigive Skibene og fremtidigt give Aabenraaskibene frit Lejde. Samtidig sendte Borgmester og Raad en vis Friedrich Arnkiel med Fuldmagt til Sverige for at anmode om Frigivelse af Aabenraaskibene. At netop han blev udpeget til dette Hverv, begrundedes med, at han var barnefødt i Byen og havde levet dær hele sit Liv med Undtagelse af Universitetsaarene. ${ }^{43}$ )

Samhandelen med Sverige var altsaa en Livsnødvendighed for Byen. Intet Under derfor, at dens ansvarlige Mænd paa alle mulige Maader søgte at opretholde denne Forbindelse, selv om

43) Sommersemestret 1699 besøgte han saaledes Universitetet i Leipzig (Heimatblätter aus Nordschleswig 1940, S. 69). 1723 4./6.-1728 3./2. var han Borgmester i Aabenraa. Født 1681 10./2. som Søn af Provst Trogillus Arnkiel. 
det maatte ske ved samtidig at staa i Kontakt med baade den danske Konge, den gottorpske Hertug og de svenske Myndigheder. Trods alle Anstrengelser har det dog ikke været muligt at opretholde denne Trafik. Krigsaarene efter 1714 blev derfor yderst daarlige Aar for Byens Borgere.

Allerede 1714 lød der Klager over, at man ikke havde kunnet udnytte Sommertiden til Sejlads. Dertil kom, at mange Skibe var holdt tilbage eller konfiskeret i Sverige. Blandt dem, som det var gaaet ned ad Bakke for, var forannævnte Chr. Kaadt, hvis Skibe var taget som Prise.

Efter Fortegnelsen over Borgere, som i 1714 erlagde Krigsog Formueskat, betalte følgende over $\left.10 \mathrm{Rdl} . .^{44}\right)$

\begin{tabular}{|c|c|}
\hline Købmand ${ }^{45}$ ) Hinrich Frellesen Frees & 36 \\
\hline Købmand $^{45}$ ) Jørgen Paulsen & 32 \\
\hline Farver Martin Bahnsen & 28 \\
\hline Købmand ${ }^{45}$ ) Jørgen Barsøe & 26 \\
\hline Købmand $^{45}$ ) Jacob Biørnsen & 26 \\
\hline Købmand ${ }^{45}$ ) Knudt Jacobsen & 26 \\
\hline Købmandsenke Margr. Thielsen & 26 \\
\hline Købmandsenke Dorothea Beyer & 24 \\
\hline Skipper Oluf Rudebeck & 20 \\
\hline Skipper Fester Jessen & 16 \\
\hline Købmand ${ }^{45}$ ) Jacob Sedin & 14 \\
\hline Raadmand $^{45}$ ) Johan Gorrisen & 12 \\
\hline
\end{tabular}

7: Defølgende Aar led Byen smertelige Tab ved Kapringer og Tilbageholdelser. Derimod var de Tab, der blev lidt i kongelig Tjeneste, forholdsvis ringe, idet Aabenraaskibe først den 19. 7. 1717 blev taget til Transporter for den danske Flaade. De, der forliste i kongelig Tjeneste, fik senere Erstatning, men det blev $1713-44$.

44) LA. Aab. Byarkiv VIII 120a. Krigs-, Formue- og Næringsskat

45) Var alle tidligere Skippere, som til Dels var gaaet over til Rhedervirksomhed. 
kun til fem Skippere for Aabenraas Vedkommende. ${ }^{46}$ ) Mange Skippere blev derimod opbragt af Svenskerne, andre synes fortsat at have spillet under Dække med Svenskerne, saa de kun af Navn var beslaglagt. Skipper Jens Hinrichsen, som i Aabenraa var meldt opbragt af Svenskerne, blev saaledes opsnappet af den danske Flaade og ført som Prise til København. 1719 blev en kendt Aabenraaskipper, Fester Jessen, opbragt af "Moscowiterne“ i Nærheden af Reval og "belagt" med haardt Fængsel. Ogsaa han har vel haft Maskepi med Svenskerne, der jo ogsaa var Russernes Fjender.

Tabene til Søs var alt i alt ikke ringe, men endnu værre var det, at den indbringende Fart paa Sverige var standset. 1718 sukkede Magistraten da ogsaa over, at Byens Borgerskab i den Grad var svækket, at de, som før havde nogen Formue, nu næsten var de daarligst stilledes Ligemænd. Blandt Aarsagerne hertil regnedes naturligvis ogsaa de store Skatter, der fulgte $\mathbf{i}$ Krigens Spor. En Del af de fra Nabobyerne tilflyttede Borgere søgte derfor igen væk fra Aabenraa. En udenbys Skipper nævnte saaledes i 1715, at han havde været nødsaget til paa et vist Aaremaal at tage Borgerskab i det daværende neutrale Aabenraa, ${ }^{47}$ ) fordi Kongens Arveundersaatters frie Sejlads i Østersø og Nordsø var blevet hæmmet af Svenskerne, men nu onskede han at blive lest fra sit Borgerskab.

Byens Borgere har dog ikke været slaaet helt ud. Da Sverigesfarten var standset, maatte man slaa ind paa nye Veje: man udnyttede derfor nu fuldt ud Forbindelserne med England. Aabenraas vigtigste Indførselsartikel i de følgende Aar blev en-

48) RA. Krigskancelliet. Indsendte Relationer om lidt Krigsskade. Besvarelse af Overkrigssekretærens Cirkulære af 1721 15./2. I Sønderjyllands Historie Bd. III, S. 290 er der ved Sammenligning mellem Sønderborg og Aabenraa sket en Fejlslutning, idet Sønderborg jo som kongelig By allerede siden 1709 maatte deltage i Transporter for den danske Flaade og som Følge heraf led større Tab i kongelig Tjeneste end Aabenraa.

47) LA. Aabenraa Byarkiv V 11. Borgerbreve og Korrespondance vedr. Optagelse i Borgerskabet. 1709-1869. 
gelsk og til Dels fransk Salt, som blev oplagret i Byen og videresolgt til slesvigske, tyske og danske Havne. For at skaffe sig Penge havde den danske Konge den 9. 8. 1712 imod et aarligt Vederlag givet et Konsortium Eneret paa Handelen med lüneburgsk Salt i Hertugdømmerne, dog undtagen Flensborg. ${ }^{48}$ ) Den 3. 10. 1712 tildelte Hertugen derpaa Aabenraa fri Handel med engelsk og fransk Salt paa den Betingelse, at det blev reeksporteret. Ikke des mindre sank Forbruget af Lüneburgersalt allerede i 1713 til en Femtedel. I 1715 solgtes endog kun 24 Tdr. af det lüneburgske Salt i selve Aabenraa. Saltoktrojens Folk kom derfor til at føre en haabløs Kamp mod det engelske og franske Salt ${ }^{49}$.)

Imidlertid kom det til Rivninger mellem Byen og dens nye Øvrighed. Hidtil havde Aabenraas Toldopkrævere regnet 1 Td. lüneburgsk Salt lig 2 Tdr. engelsk og skotsk Salt. Paa den Maade var engelsk og skotsk Salt jo blevet betydeligt billigere i Told- og Licentafgifter. Dette blev nu forbudt, og det blev den 13. 6. 1716 paalagt Byen at føre nøje Kontrol med Salthandelen..$\left.^{50}\right)$ Det nyttede lidet, at Byens Talsmænd fremhævede, at siden det Tidspunkt, det engelske Salt var blevet ført til Landet, havde man $i$ den "fyrstelige Tid lige indtil Sekvæstrationen" hver Gang regnet $2 \mathrm{Tdr}$. engelsk Salt lig $1 \mathrm{Td}$. lüneburgsk, derimod var det aldrig blevet regnet lig det franske eller spanske Salt. Overhovedet synes Kontrollen med Toldregnskaberne at være blevet udøvet adskilligt skrappere under det nye Styre end tidligere. At man ved Uregelmæssigheder undskyldte sig med, at man havde beregnet Tolden "nach hiessiger Usance“, blev ikke mere taget for gode Varer.

I det hele taget synes det materielle at have spillet langt den største Rolle hos Datidens Aabenraaborgere. Havde man Fordel af den gamle Tilstand, raabte man op om, hvordan det hidtil

48) RA. T.K.I.A. B. 157. Akter vedrørende den lüneburgske Saltoktroj i Hertugdømmerne og dens Ophævelse 1718-39.

49) Herom nærmere i Sønderjydsk Maanedsskrift 1947. S. 85 ff.

50) RA. Aab. Toldregnskaber 1713-33 (omf. kun Aarene 1716-33). 
havde været Skik og Brug; man ønskede at gaa frem "nach alter Usance", som er et hyppigt anvendt Udtryk. Dog ønskede man samtidig at drage alle de Fordele af det nye Styre, der kunde byde sig. Man foreslog saaledes nu Toldfrihed for Handelen mellem „Dännemarck" og Aabenraa. ${ }^{51}$ ) Det dansk-norske Marked burde aabnes for Aabenraas næringsdrivende, med andre Ord: man ønskede at blive ligestillet med Flensborg.

Efter Indlemmelsen havde Aabenraaerne eksporteret Hør til Kongeriget uden at svare Licent deraf. Ligesom Salt var Hør nu blevet en af Byens vigtigste Handelsvarer. Hør skaffede man sig ad Søvejen fra Riga, Königsberg og Danzig; derimod rævnes det udtrykkeligt, at man ikke handlede med lüneburgsk, hollandsk eller hjemmeavlet Hør. Overhovedet foregik Aabenraas Fjernhandel i Krigsaarene i en ny Cyklus: man sejlede nu til Vesteuropa med Korn fra de danske Øer og tog Salt med tilbage. Dette afsattes igen paa Grund af Saltoktrojen for største Delens Vedkommende i de nordtyske og baltiske Havne, hvorfra man bragte Hør hjem, som saa igen afhændedes i danske Havne. Det svenske Tømmer spillede derimod ingen Rolle i disse Aar.

Men lige saa snart Freden igen havde holdt sit Indtog i Norden, blev den aabenraaske Import af Trælast, Jern, Kalk og Tjære fra Sverige genoptaget. At det ikke drejede sig om helt ubetydelige Mængder, kan man se deraf, at af de 306 Fartøjer, som i Løbet af 1724 afsejlede fra Gotland, var de 60 hjemmehorende i Aabenraa. I Aaret 1744 udgjorde Aabenraaskibene 115 af de ialt 354 Skibe, som i dette Aar forlod nævnte $\varnothing^{.52}$ )

Foruden denne Handel forøgedes ogsaa Handelen med andre Egne, da Aabenraaskipperne stadig udvidede deres Virkefelt. Som en Følge af den nye Statsforbindelse begyndte de nu ogsaa at sejle i Fragtfart for københavnske Købmænd. 1723 var saa-

51) RA. Aab. Toldregnskaber $1713-33$.

52) Efter M. Michelsen: Aabenraa Bys Søfart. (Sønderjydsk Maanedsskrift, 16. Aarg. S. 222). 
ledes 3 Aabenraaskibe befragtet af disse for Sejlads paa Is-land. Endvidere besørgede Aabenraaskibe for københavnsk Regning en Del af Fragtfarten mellem de svenske Tømmerhavne og den danske Hovedstad.

I Anledning af den store Brand i København i 1728 blev Aabenraaskipperne saavel som det søfarende Folk fra Nabobyerne Flensborg og Sønderborg beordret til at sejle Sten fra Teglværkerne ved Flensborg og Aabenraa til den brandhærgede Hovedstad..$^{53}$ ). Denne Opgave huede imidlertid slet ikke Skipperne, da Fragten betaltes for daarligt. Uden Held gjorde man fra Byens Side opmærksom paa, at Sønderborg og Eckernförde laa nærmere Teglværkerne omkring Flensborg Fjord og cierfor først burde tages til disse Transporter. I Modsætning til de andre Byer havde Aabenraa intet Opland, som den kunde leve af, men var udelukkende henvist til Søfarten. To aarlige Transporter med Sten vilde hindre dem i at komme tidsnok paa I.angfart til Nordsøen, til Irland, England og Frankrig.

Amtmand von Massow forlangte derefter den 9. 12. 1729 en Opgørelse over Byens Handelsflaade, der da omfattede 59 Enheder paa ialt 1643 Læster. I Foraaret 1730 var Aabenraaskibene bestemt til følgende Sejladser: 18 skulde til Sverige, 5 til Norge, 3 til Island, 2 til England, 3 til Frankrig. Endvidere skulde 3 sejle paa Østersøen, 1 til dansk Havn, 2 skulde til Riga og 2 til tyske Havne. 11 havde derimod endnu ingen Bestemmelse taget. 9 Skibe var endelig allerede gaaet i Gang med Murstenstransporterne til København. Blandt de optalte Skibe betegnedes 5 paa tilsammen 134 Læster som "saakaldte svenske Skibe“. Utvivlsomt tilhørte de nogle Aabenraaskippere, som først efter Krigen var vendt hjem derfra. Foruden disse nævnes 4 mindre Fartøjer paa ialt 73 Læster, som ejedes af svenske Interessenter, en Følge af den mangeaarige Handelsforbindelse mellem Aabenraa og Sverige.

i3) LA. Aab. Byarkiv VII 106a: Angaaende Forsendelse af Mursten til København 1729-31. 
Hele Aaret 1730 maatte Aabenraaskipperne dog trods alle deres Indsigelser sejle Sten til København. Aabenraateglværkerne fik travlt. Provst Chr. Gottlieb Koch, der ejede Teglværket paa Jørgensgaard, tilbød at levere 200.000 Mursten og 10.000 Teglsten. Men Regeringen onskede omgaaende Levering af 400.000 Sten, og Størrelsen paa dem skulde være $9 \times 4^{1 / 4}$ Tommer. Ffter at Hovedstadens nødvendige Behov imidlertid var dækket, kom der den 23. 2. 1731 et kongeligt Brev med Meddelelse om, at for Fremtiden kunde Fragt af Mursten ske frivilligt. Glade over, at Afbrydelsen af deres livsnødvendige Søhandel denne Gang kun varede saa kort Tid, har Aabenraaborgerne da kunnet genoptage deres aarlige Fragtfarter.

8: Alene det, at der var Fred, betød for Datidens Mennesker en god Tid. Den følgende lange Fredsperiode fra 1720 til Begyndelsen af 1800-Tallet var til Gavn for Aabenraas okonomiske Liv. Aarene omkring 1730 var ganske vist for Landet som Helhed ret daarlige Aar med yderst lave Kornpriser. For Aabenraaerne, der næsten ingen Kornhandel havde, var de lave Kornpriser dog ikke katastrofale. Fredsaarene med de relativt sikre Kaar, de bød Handel og Søfart, har uden Tvivl ydet det største Bidrag til at gøre Aabenraaborgerne loyale over for del nye Stvre.

Skipperne var saa afgjort Byens førende Mænd i det behandlede Tidsrum. Som Byens mest formuende Borgere tog de større Skippere ogsaa virksomt Del i Bystyret. Efter Caspar von Salderns Død i 1722 overtoges Borgmesterstillingen af en kendt Skipper, Owe (Aue) Friedrich Rolfsen. Han døde dog allerede samme Aar. Flertallet af Byens Raadmænd var Skippere. Der kan nævnes Navne som Hinrich Frellesen, Knudt Jacobsen, Jacob Sedin, Jacob Biørnsen, Johan Gorrisen og Wolle Rudbeck. Sidstnævnte er kendt som Navngiver til Wollesgyde, der laa i Udkanten af Datidens Aabenraa.

I Aarene omkring 1700 lagdes Grunden til den aabenraaske Skibsfart paa fjerne Kyster. Fra at have været lidt Fragtfart i 
de nærmeste Farvande voksede i disse Aar Omfanget af Aabenraaskippernes Forbindelser til ogsaa at gælde fjernere Egne. Mens Aabenraa i Aarene før den Store nordiske Krig stadig havde været afhængig af Nabobyen Flensborgs overmægtige Handel, bragte de gunstige Aar før 1713 Aabenraaerne til i stedse højere Grad at staa paa egne Ben. Fra at have staaet i Skyggen af Flensborg, blev Aabenraa nu Søfartsby jævnsides med Flensborg, omend sidstnævnte vedblev at være den førende af de to. Men mens Flensborg og de andre slesvigske Byer havde en udstrakt Landhandel, var Søhandelen absolut det primære for Aabenraa. Næppe nogen By i den danske Konges Besiddelser var i den Grad præget af Søfarten som Aabenraa, og saaledes var Forholdet til langt op i det 19. Aarhundrede. 
Bidrag til Aabenraas $\varnothing$ konomiske Historie indtil ca. 1730.

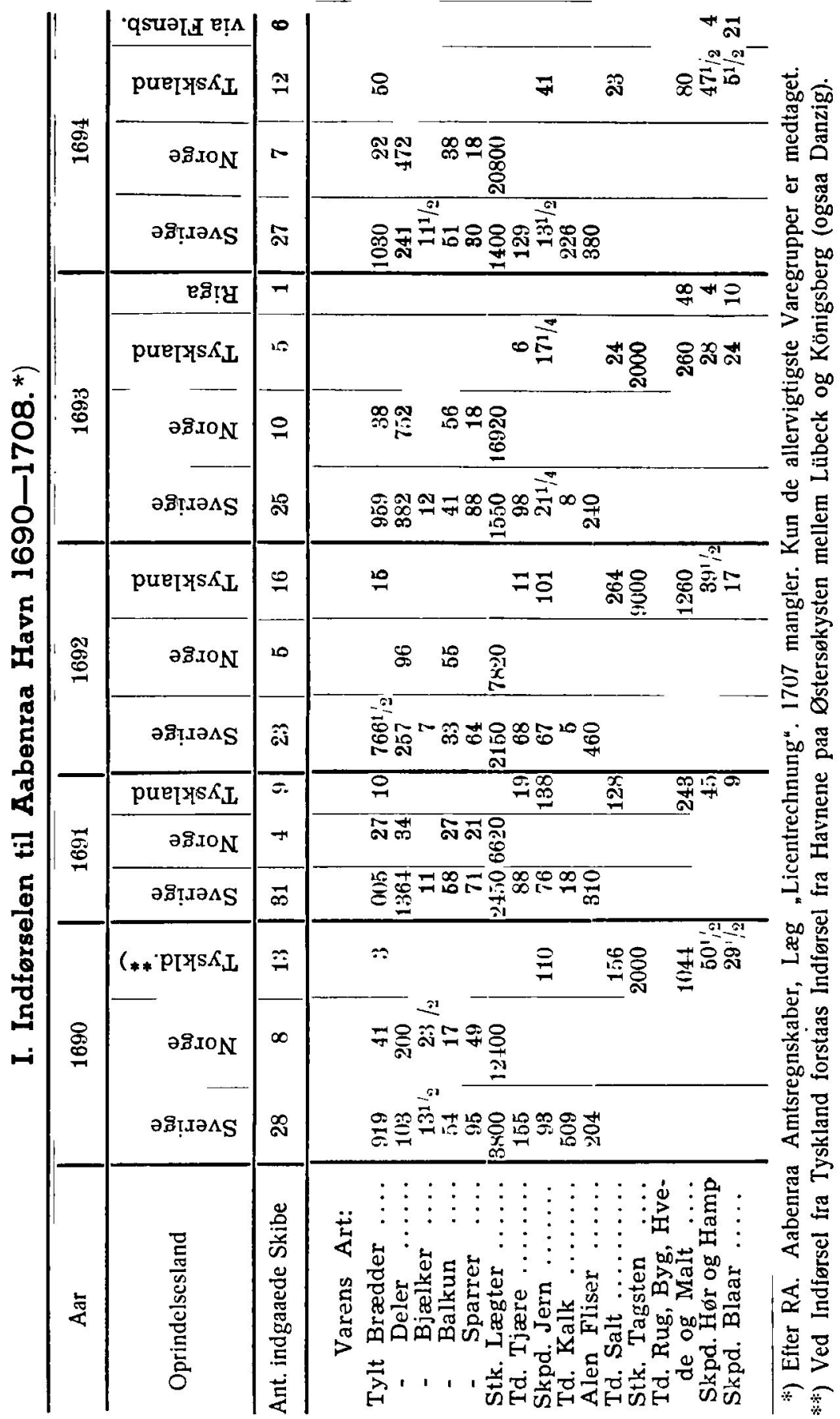


Hans Vald. Gregersen.

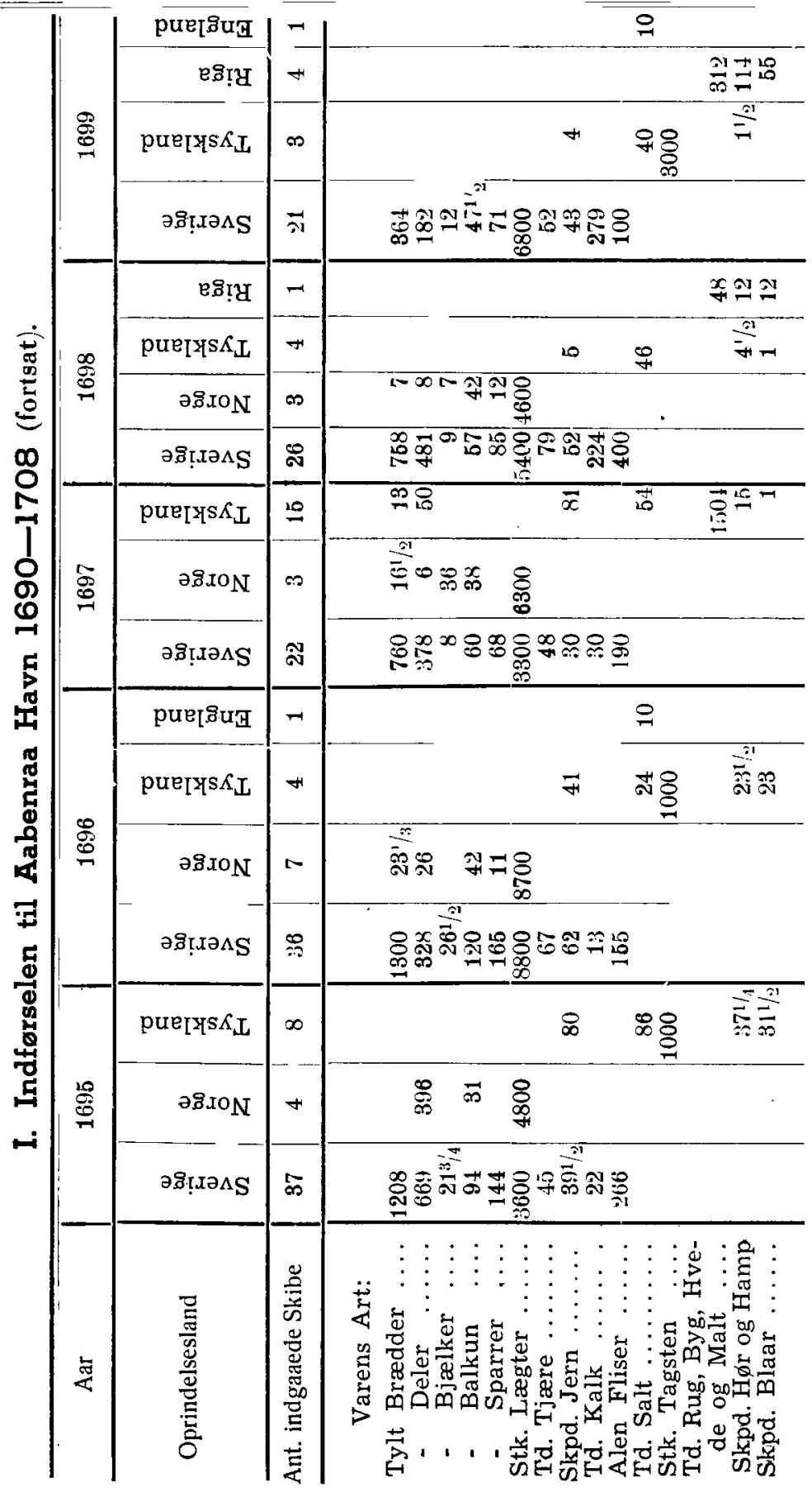


Bidrag til Aabenraas $\varnothing$ konomiske Historie indtil ca. 1730.

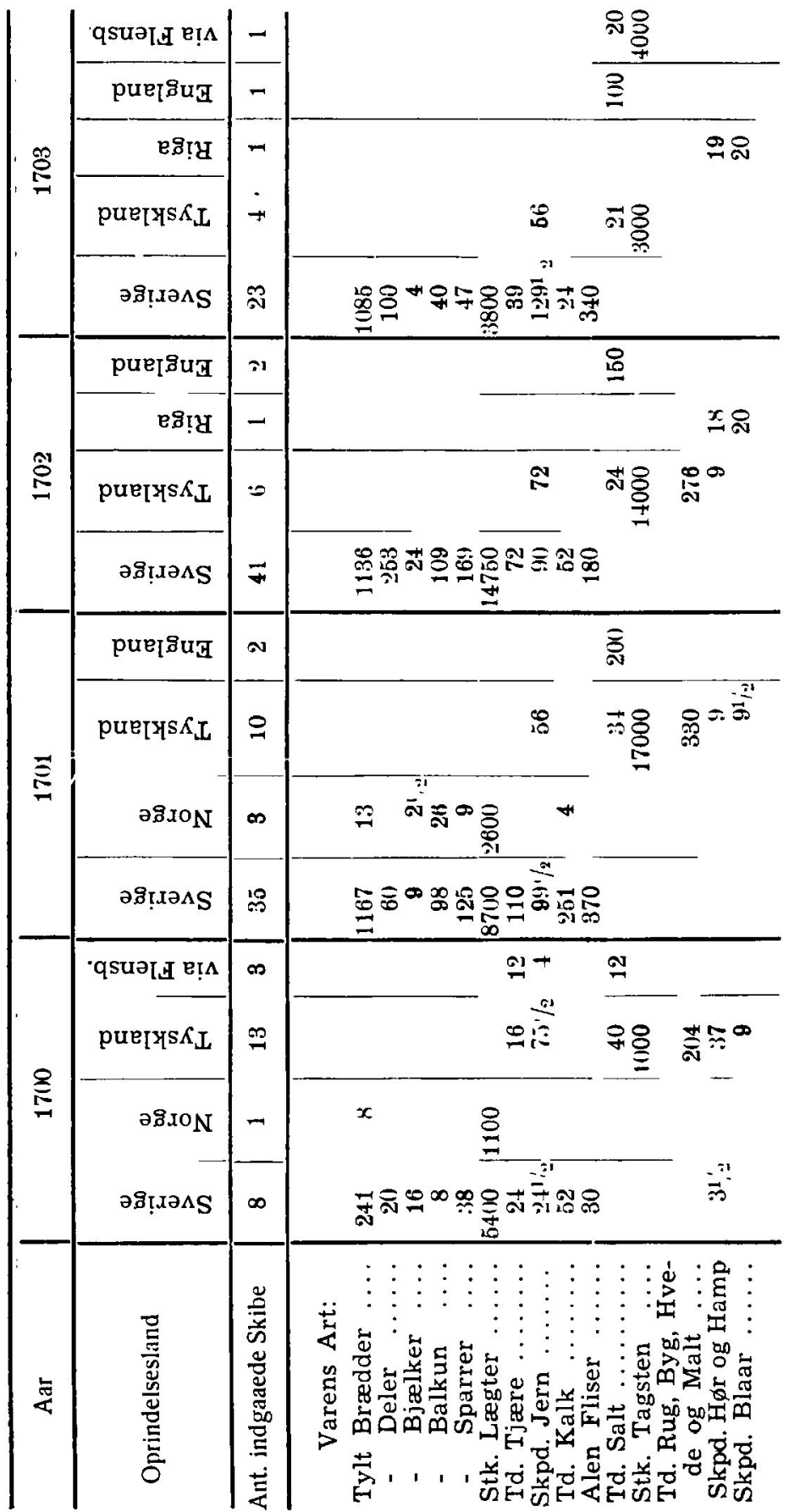




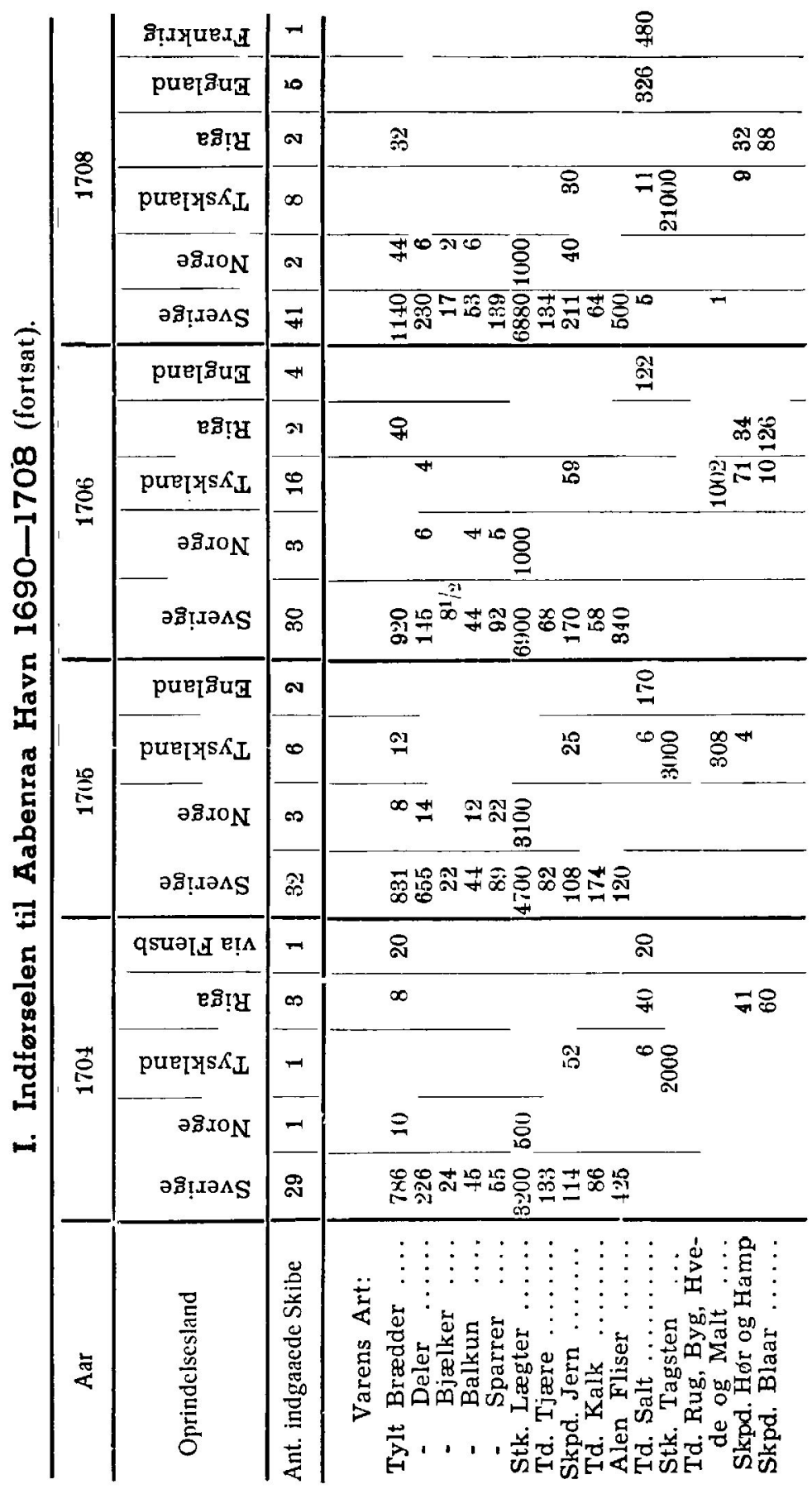


Bidrag til Aabenraas $\varnothing$ konomiske Historie indtil ca. $1730 . \quad 89$

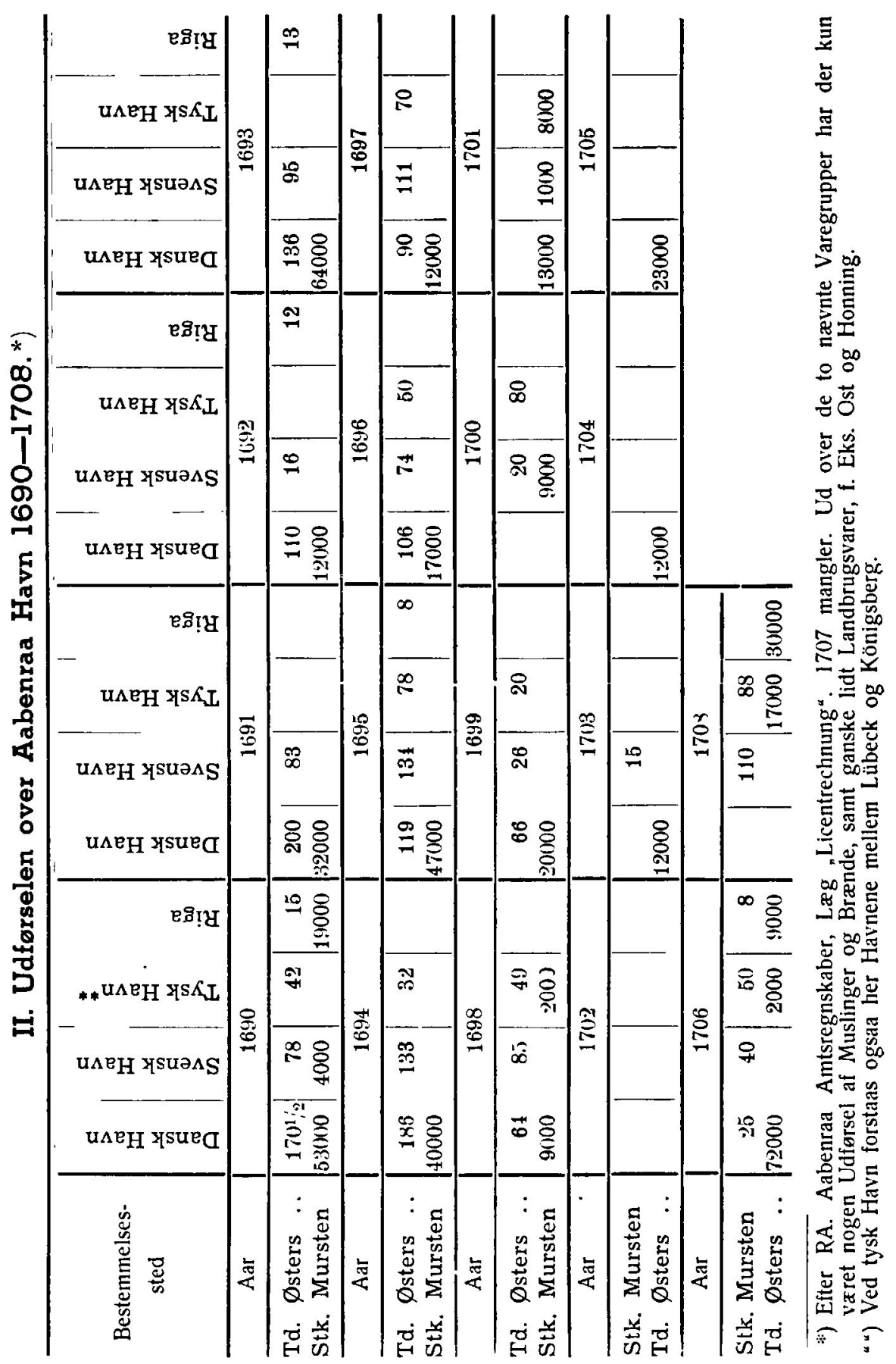




\section{Den sognevise Fordeling af Aabenraas Tømmer- udførsel til Oplandet for Aaret 1705*)}

\begin{tabular}{|c|c|c|c|c|c|}
\hline & Vog & læs & & & alæs \\
\hline Ris Herred: & Ris & 13 & & Skærbæk & 25 \\
\hline & Bjolderup & 61 & & Spandet & 13 \\
\hline & Hjordkær & 98 & & Vodder & 2 \\
\hline & $L \emptyset j t$ & 19 & Ribeegnen: & Ribe & 2 \\
\hline Sdr. Rangstrup & Bedsted & 11 & & Farup & 5 \\
\hline Hrd.: & Hellevad & 2 & & Seem & 2 \\
\hline & $\emptyset$. Løgum & 16 & & V. Vedsted & 7 \\
\hline Lundtoft Hrd.: & Ensted & 7 & Haderslev Hrd.: & Haderslev & 13 \\
\hline & Holb $\varnothing 1$ & 1 & & Hoptrup & 6 \\
\hline & Kliplev & 5 & & Vilstrup & 11 \\
\hline & Uge & 58 & Nr. Rangstrup & Agerskov & 37 \\
\hline Slogs Herred: & Burkal & 47 & Hrd.: & Bevtoft & 66 \\
\hline & Bylderup & 31 & & Branderup & 9 \\
\hline & Hostrup & 52 & & Tirslund & 3 \\
\hline & Rabsted & 91 & & Toftlund & 33 \\
\hline & Tinglev & 15 & Gram Herred: & Gram & 1 \\
\hline & $\emptyset$. Højst & 60 & & Hammelev & 3 \\
\hline Tonder Hrd.: & Tønder & 41 & & Jægerup & 1 \\
\hline & Abild & 30 & & Nustrup & 12 \\
\hline & Daler & 22 & & Sommersted & 2 \\
\hline & Møgeltønder & 1 & & Vedsted & 28 \\
\hline & Ubjerg & 6 & Vis Herred: & Flensborg & 1 \\
\hline & Visby & 12 & & Bov & 12 \\
\hline Lø Herred: & Løgumkloster & 37 & & Hanved & 1 \\
\hline & Nr. Løgum & 50 & & Nr. Haksted & 1 \\
\hline & Brede & 37 & Kær Herred: & Braderup & 8 \\
\hline & Døstrup & 32 & & Humtrup & 1 \\
\hline & Mjolden & 7 & & Karlum & 1 \\
\hline & Randerup & 4 & & Klægsb $\varnothing 1$ & 3 \\
\hline Højer Hrd.: & Højer & 7 & & Ladelund & 4 \\
\hline & Ballum & 19 & & Læk & 4 \\
\hline & Emmerlev & 21 & & Stedesand & 1 \\
\hline & Skast & 1 & & Sdr. Løgum & 3 \\
\hline Hviding Hrd & Hviding & 1 & Viding Hrd.: & Ialt & 10 \\
\hline & Brøns & 10 & Bøking Hrd.s & Lindholm & 1 \\
\hline & Arrild & 7 & & Nibøl & 1 \\
\hline & Rejsby & 8 & & Risum & 10 \\
\hline & Roager & 4 & Nr. Gøs Hrd.: & Bredsted & 11 \\
\hline
\end{tabular}

*) Efter RA. Aabenraa Amtsregnskaber, Læg Zollrechnung. 
Bidrag til Aabenraas $\emptyset$ konomiske Historie indtil ca. 1730.

\section{Aabenraas Handelsflaade 1713 og 1730}

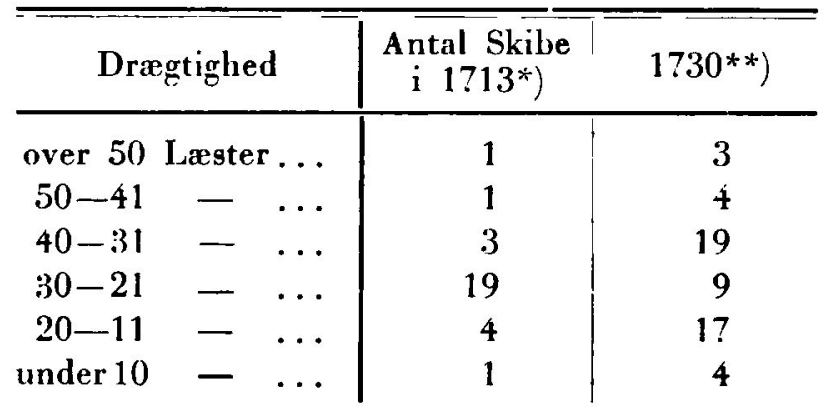

\%) Efter H. Schlaikier: Aabenraa Sufarts Historie, S. 137. Muligvis er denne liste ufuldstændig.

(9) Efter LA. Aab. Byarkiv VII $106 \mathrm{a}$. 